\title{
IS RESTORATIVE JUSTICE AN APPROPRIATE LEGAL REMEDIATION FOR SEXUAL VIOLENCE?
}

\author{
Ena Kazić ${ }^{*}$ and Rialda Corović**
}

\begin{abstract}
This paper questions applicability of restorative justice in cases of sexual violence. Specific nature and serious consequences of sexual violence are the reason why this question has appeared. In order to find out the answer, the authors have presented the characteristics, mechanisms and nature of restorative justice, concurrently offering the comparison of arguments in favor of and against the applicability of restorative justice in this particularly sensitive type of criminal offences. Together with the review of diverse theoretical approaches to this matter, the authors have tested the applicability of restorative justice in cases of sexual violence in Bosnia and Herzegovina. In this paper normative, comparative and historical scientific methods have been used.
\end{abstract}

Key words: Criminal offence, sexual violence, restorative justice, victim.

\section{INTRODUCTION}

The establishment of restorative justice, brought about by the criticism of the application of retributive justice over the centuries, gave hope to both scholars and practitioners that the voice of victims would be heard (more) loudly and that a new cathartic approach toward the perpetrator

\footnotetext{
Assistant Professor at the Faculty of Law, International University of Sarajevo, e-mail: ekazic@ius.edu.ba, e.kazic12@gmail.com.

${ }^{* *}$ Legal Advisor at the High Judicial and Prosecutorial Council of Bosnia and Herzegovina,rialda_87@hotmail.com
} 
would facilitate the preventive function, which is a goal of the criminal law system ${ }^{1}$. In 1970, restorative justice, which was a natural method of solving conflict in some native cultures for centuries ${ }^{2}$, turn to be modern criminal law movement that spread fast within contemporary criminal law systems. From that period until now, restorative justice has gone through growing pains ${ }^{3}$ and in the contemporary criminal law it has consistently gained credibility as a powerful alternative to the traditional responses to crime throughout the world. For those states that haven't introduced it at all or just minimally, there are recommendations given on the international level for it to be introduced and applied into the criminal law ${ }^{4}$. A good example is the recommendation to the Member States to "facilitate the referral cases as appropriate to restorative justice services, together with establishment of procedures and guidelines" from Article 12 of Victims Directive 2012/29/EU, which raises the awareness of the necessity for turning towards restorative justice.

1 Marilin Armour states that eighty-five studies and four meta analyses that have been generated over the past thirty years show consistently high rates of participant satisfaction in a variety of forms of restorative justice applications. For example, the recent meta analysis of 12000 juveniles in juvenile cases has shown " 25 percent reduction in recidivism, leading the researchers to claim that victim-offender mediation is a well-established, empirically supported intervention for reducing juvenile recidivism”. See at: Marilyn Armour, "Restorative Justice: some facts and history", July 20, 2018. https://charterforcompassion.org/restorative-justice/restorative-justice-some-facts-and-history.

2 Aboriginals, Maori, Native Americans and other native cultures are representatives of cultures that used original forms of restorative justice for centuries in order to resolve the conflict and bring the justice. "The Origins of Restorative Justice". May 29, 2018, http:// www.restorativeapproaches.eu/origins.

3 In this paper the process of acceptance of restorative justice is referred to as „growing pains" since it has taken time for practitioners who had been applying traditional retributive system for years to understand benefits of restorative justice and positive results of its implementation. Until that has happened, it had been usually underestimated and ignored. Apart from the problem of introducing restorative justice de lege, nowadays it is questioned how much of restorative justice is applied de facto.

4 One of them is for instance Victims Directive 2012/29/EU, which is according to Emanuella Biffi „the first binding and enforceable legal instrument at the EU level that defines restorative justice and provides the legal safeguards to protect victims of crimes informed about and participating in a restorative justice process". See: Emanuella Biffi, Practice Guide To Rj Services: The Victims' Directive: Challenges And Opportunities For Restorative Justice, (2016): 4. 
Even though we can testify to its evolution and point out numerous discussions and debates among scholars and practitioners on general aspects of restorative justice, it is important to wonder whether restorative justice is applicable to all criminal offences, regardless of their natures. Particularly, the subject of our interest in this paper is to establish whether restorative justice is applicable to sex offences.

The reason for our concern for this particular group of criminal offences is their specific nature. Sex offences are neither a new group of criminal offence nor a territorially limited negative social phenomena. Some of them existed even in the ancient times ${ }^{6}$ and are present even nowadays throughout the world in a variety of forms ${ }^{7}$. The nature of sex offences is what makes them peculiar as compared to other criminal offences. They are deeply intimate criminal offences, which even when diverse in its forms, cause universally scientifically recognised consequences to victims ${ }^{8}$. Those

5 Their nature is correlated to the object of protection. Some criminal offences are more intimate (crimes against family, sexual liberties and moral), some of them don't have recognisable victims and therefore lack the intimate nature (crimes of endangerment).

6 For instance in Roman Law, Rape as a criminal offences existed to protect both males and females. More in: MarinkaCetinić, «Pogled na pitanje da li je potrebno preispitivanje inkriminacije silovanja», u Anali Pravnog fakulteta u Beogradu, Pravni fakultet u Beogradu, Beograd, (1995): 81.

7 See World Health Organization Report On Sexual And Reproductive Health, https://www.who.int/reproductivehealth/topics/violence/sexual_violence/en/.

8 Consequences of sexual violence usually fall into physical, psychological and social categories. Physical consequences are all possible forms of violation of physical health of victim. According to the $\mathrm{WHO}$, they include bruises, vaginal bleedings, infections, fibroids, genital irritations, etc. One of them is (unwanted) pregnancy which is in $18 \%$ a common consequence of rape in Ethiopia and in 15-18\% in Mexico. See more in: WORLD Report On Violence And Health, World Health Organization, 2002., www.who.int/violence.../ violence/world_report/en. Psychological consequences last even longer than physical ones and they directly control the possibility of a victim to reintegrate into society after the critical event. They might be: frigidity, lack of sexual interest, lack of self-confidence, lack of trust and confidence towards others, apathy, depression, etc. See in World Report On Violence And Health, World Health Organization, 2002., www.who.int/violence.../violence/ world_report/en, [last access: 10.07.2018]. Social consequences are dependent on the type of society and community a victim lives in. For example, in traditional societies, victims of sexual violence are stigmatized and in various cases, because of the lack of empathy and understanding from society, it founds them responsible for their own victimization. Instead of being protected as a victim, they are being judged and secondarily victimized. 
criminal offences are violating victim's sexuality, intimacy, and trust. They are leaving life-long feeling of shame and pain and questions unsolved such as "why has this happened to me?", "am I the one to be blamed?", "how am I going to trust another person ever again?". Perpetrators (sometimes) don't regret and even don't see their victim as a vulnerable human being who has to live with the consequences of their crime for their lifetime. If the tools of restorative justice involve the active participation of the victim and the offender in the resolution of the conflict and require their interaction, then we have to wonder what their interaction in cases of sex offences would be like or would it be possible at all?

The deep consequences of those crimes have required society to classify such actions as criminal offences and to establish criminal sanctions for its perpetrators. Presently, all countries in the world have parts of their criminal codes that define which actions are deemed sex offences ${ }^{9}$. The important fact here is that there is collective conscience of all of society for a reaction, a prevention, and a condemnation of those actions ${ }^{10}$. Having that in mind, it is doubtless that there is constant emphasis on prevention of those criminal offences.

9 The content of those provisions is globally varied in terms of forms of actions and sanctions. For example, entire chapters of some modern criminal codes are devoted to incrimination of sex offences: the Criminal Code Of Federation Of Bosnia And Herzegovina, Chapter 19, „Criminal Offences against sexual liberties and morality“; the Criminal Code Of the Republic Of Germany, Chapter 13, „Criminal Offences against sexual orientation“; the Criminal Code Of the Republic Of France, Chapter 2, „Criminal Offences against physical and psychological integrity“. While some sex-violence-including actions are criminal offences in one country, they might not be criminal offences in other countries; while some of them in the same country are being decriminalized throughout time, some of them are being criminalized (For example, while in the Criminal Code Of the Federative Nation Republic Of Yugoslavia from 1951, in Article 186 had prescribed criminal offence „Unnatural adultery ", that referred to a sexual activity between men. Bosnia and Herzegovina, that is its successor doesn't incriminate homosexuality as unnatural adultery or as a criminal offence).

10 Except for general international conventions and declarations (for example: $U N$ Declaration On Human Rights, Convention on the Rights of the Child), there are special documents that refer to sexual violence such as: Declaration on the Elimination Of Violence Against Women (1993), Convention Of Council Of Europe on Action Against Traffcking in Human Beings (2005), The Council of Europe Convention on preventing and combating violence against women and domestic violence (2011). 
The aim of this paper is to establish if the application of restorative justice, for the purpose of crime prevention, would be possible for such deeply intimate cases, or would its mechanisms result in creation of an environment for the possibility of a secondary victimization. Assisted with dogmatic, normative, and comparative scientific methods, this discussion will fall into three main parts: Part II is a brief overview of restorative justice, establishing its aim and its principles and tools, so that they may be tested as to whether they would be appropriate to use for sex offence cases. Part III identifies all possible benefits of its application together with examples of successfully applied restorative justice in those cases. Finally, Part IV questions the applicability and eligibility of restorative justice in sex offence cases in Bosnia and Herzegovina, by bringing in the correlation of positive criminal law provisions referring to restorative justice and sex offences.

\section{DEFINING RESTORATIVE JUSTICE}

The term restorative justice is believed to have been invented and first used by Albert Eglash in 1977, who noted three types of a criminal justice system: "a retributive justice based on the penal system; a distributive justice based on the therapeutic treatment of the offender, and a restorative justice based on restitution, or compensation of the damage caused by the criminal offence". ${ }^{11}$ During the nineteen-seventies, the inefficiency of the traditional retributive criminal justice system had become a "trigger" for many critical comments. Classical, retributive justice, that had consisted of the idea of punishment for the perpetrator and the condemnation for his criminal actions, existed for centuries. ${ }^{12}$ According to Cragg “...punishment seems to conflict with values like forgiveness, mercy, compassion,

11 See in: Theo Gavrielides, Restorative Justice Theory and Practice: Addressing the Discrepancy, Helsinki: European Institute for Crime Prevention and Control (2007): 21. In that sense see also: Ena Kazić, Rialda Ćorović (2019) "Restorative Justice Within Legal System of Bosnia and Herzegovina" in Restorative Approach and Social Innovation: From Theoretical Grounds to Restorative Practices, University of Padua, Italy, 168.

12 See in: Kathleen Daly, Restorative Vs. Retributive Justice, Centre for crime and justice studies, No. 60 (2005). 
and benevolence, all of which reflect non-punitive ways of solving problems of human conflict"13. The preventive function of the criminal law in practice couldn't have been guaranteed since some perpetrators negated its preventive function by perpetrating new criminal offences after being released from prison.

The relation between the perpetrator and the victim was primary unfriendly, their communication ended with the criminal offence, and during criminal procedure their interests were confronted. The victims' role were of secondary importance, even though the entire criminal proceeding started because the critical action towards that victim had been perpetrated. According to Christie ${ }^{14}$, the state stole the conflict from its original owners (perpetrator and victim). That is why this traditional, retributive system of criminal justice was the subject of criticism $^{15}$. Hudson ${ }^{16}$ states that retributive justice has failed in cases where victims are women and when it comes to intimate violence. Additionally, Cragg notes that "retributive justice is incompatible with values like compassion and it has inhuman aura" 17 .

This criticism has spurred the invention of new, alternative methods of responding to crime, which are more human, more efficient and deprived of their retributive properties ${ }^{18}$. Under the strong influence of the develop-

13 W. Cragg, The Practice of Punishment: towards a Theory of Restorative Justice, New York, (1992), 8.

${ }_{14}$ Nils Christie, "Conflicts as property", The British Journal On Criminology, (1977): 1 .

15 According to Van Ness and Strong, retributive justice didn't end up in repentance and rehabilitation. Even the rehabilitation was „simply an impossible goal“, and „,...failed policy“". They are referring to comments of other scholars, suggesting some of the reasons for failure of previous forms of justice: from the improper screening of participants, overoptimistic view of human nature, the idea that state can see the deficiencies of an offender, that subject them to the treatment with the aim to help them, but it fails. See more in: Daniel W. Van Ness and Karen Heetderks Strong,Restoring Justice: An introduction to restorative justice, Routledge, (2014): 9.

16 Barbara Hudson, "Restorative Justice: The Challenge of Sexual and Racial Violence”, Journal Of Law And Society, No.2 (1998): 243.

17 W. Cragg, op. cit., 15.

18 In that sense: Nataša Mrvić-Petrović and Đorđe Đorđević, Moć i nemoć kazne. Beograd: Vojnoizdavački zavod, (1998): 89-90. 
ment of victimology and victim protection movements, efforts have been made towards advocacy for more active involvement of the victim in the existing criminal justice system and giving the opportunity to the victim, but also the community, to participate in the process of rehabilitation of the offender. All together, this has resulted in the development of a modern concept of restorative justice, which is considered to be one of the most important achievements of the contemporary criminal justice system and criminal policy. ${ }^{19}$

Tony Marshall has defined ${ }^{20}$ restorative justice as "a procedure in which all parties, or participants in a specific criminal offense, meet, in order to decide together on the resolution of the consequences of the criminal offense and its implications for the future "21. According to Johnstone and Van Ness, it is „a constructive and progressive alternative to more traditional ways of responding to crime and wrongdoing" 22 . Additionally, they add that restorative justice "is a distinctive state of affairs that we should attempt to bring about in the aftermath of criminal wrongdoing, and which might be said to constitute the "justice""23.

Unlike the retributive criminal justice system, the restorative justice model changes the angle of viewing the phenomenon of criminality in the sense that the interest shifts towards the victim of a crime, whose interests are marginalized in the traditional criminal justice system. It also shifts the perspective towards the damaged relations between a perpetrator and a victim in a way that attempts to restore damaged relations by resolving

19 See in: Johannes Wheeldon , "Finding Common Ground: Restorative Justice and its Theoretical Construction(s) (online)", Contemporary Justice Review, Oxford: Routledge, 2009, 91.

20 According to Copić, the notion of restorative justice is one of those terms that have been mostly discussed in the modern criminal and criminological literature, but yet, there is no universally accepted definition. See in: Sanja Ćopić, „Pojam i osnovni principi restorativne pravde", Temida, vol. 10. - No. 1, Belgrade: Viktimološko društvo Srbije (2007): 27.

21 Janine NataliaClark, „The Three Rs: Retributive Justice, Restorative Justice and Reconciliation”, Contemporary Justice Review, vol. 11./No. 4./2008. Oxford: Routledge Taylor \& Francis Group. Available on: http:/www.tandfonline.com/toc/gcjr20/11/4, 339.

22 Handbook of Restorative Justice, ed. Gerry Johnstone and Daniel W. Van Ness, Willan Publishing, (2007), 6.

23 Ibid., 12. 
the conflict that has occurred. Accordingly, since the main emphasis is not on the punishment but on restoration of the broken relationship, the application of restorative justice means more humane treatment of the perpetrator, avoidance of his/her stigmatization and social exclusion as well as the improvement of reintegration and inclusion. These are the key points that differ the restorative approach from the classic retributive criminal procedure.

Like any system, restorative justice rests on a set of certain coherent principles ${ }^{24}$ that reflect its system and above all the complexity. These principles constitute a kind of a guideline for the further development of restorative justice programs and the ground work for their evolution. They recognize that the criminal offense is a violation of human relations and that the focus should be placed on repairing damages done due to wrongful actions rather than on the rules that have been violated ${ }^{25}$. According to Bazemore et al., restorative justice is based on four principles as it follows: ${ }^{26}(1)$ the perception of the crime, first of all, as a violation of people and interpersonal relations; (2) correction of damage caused by a criminal offense; (3) creating the conditions that the offender understands and takes responsibility for his work (active responsibility); and (4) reintegration of the offender and the victim.

\section{JUSTIFYING APPLICATION OF RESTORATIVE JUSTICE IN SEX OFFENCES}

Even though the concept of restorative justice is universal and where accepted should be applicable to all forms of crime, in accordance to legal conditions for its application, it is questionable whether the above-mentioned principles of restorative justice are applicable to sex offences.

24 Gordon Bazemore and Mark Umbreit, Guide For Implementing The Balanced And Restorative Justice Model, Washington: U.S. Department of Justice (1998): 14

25 Ibid., 291.

26 Gordon Bazemore and Mark Umbreit, Guide For Implementing The Balanced And Restorative Justice Model, 291. 


\subsection{Sexual Offences-Cases' Sensitivity}

If we take into consideration the definition of sexual violence given by the World Health Organization in their report titled World Report on Violence and Health, from 2002, it is quite visible that those offences include "any sexual act, attempt to obtain a sexual act, unwanted sexual comments or advances, or acts to traffic, or otherwise directed, against a person's sexuality using coercion, by any person regardless of their relationship to the victim, in any setting, including but not limited to home and work" ${ }^{27}$. Basically, those criminal offences are committed with the lack of will of a victim or by misuse of their confidence ${ }^{28}$, with intentions to violate another human's dignity.

Sexual offences are intimate offences. In those cases, there are usually two quite opposite sides of a story and the lack of witnesses. Consequently, a victim is the main witness. The intimate characteristics of those criminal offences cause them to be in dark number of crime $e^{29}$. Victims, mostly because of the shame or fear decide not to press charges (report) against perpetrators and thus very often some of those actions are never prosecuted.

The consequences that they leave are extremely serious. According to the same WHO Report ${ }^{30}$, besides the physical effects, those offences leave their traces in the psyche of victims (together with all other possible con-

27 World Report On Violence And Health, 2002.

28 Centre for Disease Control and Prevention offers the definition of Sexual Violence, that corresponds to its nature. It is as a sexual act committed against someone without that person's given consent freely. It includes: completed or attempted forced penetration of a victim, completed or attempted alcohol or drug-facilitated penetration of a victim, completed or attempted forced acts in which a victim is made to penetrate someone, completed or attempted alcohol or drug-facilitated acts in which a victim is made to penetrate someone, non-physically forced penetration which occurs after a person is pressured to consent or submit to being penetrated, unwanted sexual contact and non-contact unwanted sexual experience. See details at: "Preventing Sexual Violence". [last access: 29.05.2018], https://www.cdc.gov/violenceprevention/sexualviolence/definitions.html.

${ }^{29}$ According to Petrovic and Mesko, Dark Number of Crime is number of perpetrated but unreported criminal offences. More in: Borislav Petrovic and Gorazd Mesko, Kriminologija, Sarajevo: University of Sarajevo (2004): 38.

30 World Health Report, World Health Organization, (2002). 
sequences $\left.{ }^{31}\right)$. Having that in mind, it is disputable whether classical retributive justice would be acceptable for him/her: the form of justice where that same victim would be only a secondary subject of criminal proceedings, who would be interested in high punishment of perpetrator, and who would be (if possible without facing the perpetrator) giving a statement as the witness, fulfill its role in the criminal proceedings?! Or would it be advisable to actively involve the victim in the proceedings to make the victim responsible for the outcome of the case? Would that encourage him/her to understand that his/her opinion counts and is important for the outcome of the case? Would that bring closure to the victim?

Between those two solutions, there are some, very understandable, disputes in theory, that consequently offer reasons for and against restorative justice in sex offences cases. Wosner reviews some of the arguments against the applicability of restorative justice in those cases, which include: "[the] possible causation of stress to the victim in the moment of facing the perpetrator, secondary victimization during their meeting, and confidentiality violation." 32

But even with those understandable arguments, that author recommends the application of restorative justice, in all forms of sexual offences. ${ }^{33}$

Wosner is not the only author who argues against restorative justice in sex offences cases. Mercer et al. ${ }^{34}$ point out that mechanisms of restorative justice are riskier for sex offences than for other crimes. They express the emotional dimension of the application of restorative justice that shows up while interfacing with a perpetrator and which finally can be a trigger for the victim's re-traumatization ${ }^{35}$. Victims of sex offences are more vulnerable than in the other crimes ${ }^{36}$. Nevertheless, even though their concern in this matter is shown, in order not to generalize

31 See supra note 10 .

32 GundaWosner, "Developing Sexual Offenders Laws and Treatment in Europe", Monatsschrift fur Kriminologie und Strafrechtsreform, No. 1, (2014): 96.

33 Id, 96.

34 Vince Mercer, Karin Sten Madsen, Marie Keenan and Estelle Zinstaag, Doing Restorative Justice In Cases Of Sexual Violence: A Practice Guide, Belgium: Leuven Institute of Criminology, 2015: 13

35 Id., 13.

36 Id., 13. 
all critical situations and not to eliminate the possibility of application of restorative justice, they advise experts to make a clear distinction between restorative risks and criminological ones. While restorative risks refer to the risk present in restorative practice to create potential harm to either party, the criminologist refers to factors that made the offender perpetrate the criminal offence and may influence recidivism ${ }^{37}$. So, not every risk or harm is caused by restorative justice but instead might have a criminological cause.

\subsection{The other side of the coin}

Without any doubt, all of the above-mentioned arguments against active involvement of the victim in the solution of the victim's own case are quite understandable and reasonable. They are focused on the consequences of victimization and are results of profound research which are more of a psychological nature than legal ${ }^{38}$. Even with justified opinions against restorative justice application to sex offences, it is required to determine if there are opposite views among scholars and practitioners and moreover to establish if there are positive examples of its application in practice.

Hudson favors applying restorative justice to sexual offences, on the ground that classical criminal justice has not prevented sexual offences so far. ${ }^{39}$ Additionally, restorative justice aims to help a victim, not to make her/him go through secondary victimization but to get redress and to get to the primary importance in cases. She has analysed four very important

37 Id., 13.

38 In literature, the COSA Model (Circle of Support and Accountability) is mentioned as a possible hybrid alternative to restorative justice in the cases of Sexual Offences. It emerged in 1998 in Canada. In its basis it includes both reparation and restoration of a relationship. It consists of an inner circle (volunteers that are trained by circle coordinators) and an outer circle (community, professionals such as therapists, etc.). The research on its efficiency of prevention of recidivism shows that the COSA Model is successful since the recidivism has been reduced up to $83 \%$ in the COSA Groups. See on: „Restorative justice in cases of sexual violence“, www.just.ee, 6.

39 Barbara Hudson, Restorative Justice: The Challenge of Sexual and Racial Violence, 247. 
consequences of the application of restorative justice to sexual violence-related cases, which proves importance for the victim and the outcome of the case, and shows a desirability of the application of restorative justice to them (when possible). ${ }^{40}$

According to Hudson, those four impacts are: a perpetrator by admitting guilt in interface with a victim shows that helshe appreciates the victim; admits that a criminal offence is bad and harmful; shows that helshe is embarrassed; and understands that it would be the best for him/her to avoid perpetration of criminal offences ${ }^{41}$.

First impact would have therapeutic influence on the victim, so all questions such as "why has this happened to me?" or the fear of socialization would be overcome. The three remaining impacts would have a therapeutic and cathartic impact on the perpetrator. Namely, feeling shame for his/her wrongdoings or showing remorse to a victim would bring relief to the perpetrator and would motivate him/her to abstain from criminal offences. That would deter the perpetrator from possible recidivism into criminal activity. Accordingly, those four aspects are the most desirable outcomes of restorative justice in those cases that obviously not only are more emotionally satisfying to the victim than retributive justice (which has kept them far from interfering into the resolution of the case), since restorative justice makes the victim feel important but it may result in the prevention of crime. The preventive effective of restorative justice for sex offences cases is stressed by McAlinden, who says that "...restorative justice is more humane re-integrative approach in sex offences cases..."42 and that "...has effectiveness in prevention of such criminal offences" ${ }^{43}$.

The everlasting fear of secondary victimisation, which is used as an argument against restorative justice in sex offence cases might be questioned with McAlinden's response to it ${ }^{44}$. McAlinden calls on scientific research

40 Id. at 249.

41 Id. at 249.

42 Anne-Marie McAlinden, Restorative Justice as a Response to Sexual Offending - Addressing the Failings of Current Punitive Approaches, Sexual Offender Treatment, Vol. 3/1 (2008): 2.

43 Id.at 6.

44 Id.at 4. 
rather than to presume what might happen with the usage of restorative justice and gives a strong argument that trivializes the fear of secondary victimization as an opposing argument. In this regard, the study made in South Australia on 400 cases of sex offences has shown that conferences (as a mechanism of restorative justice) are less victimizing to a victim than the court regime ${ }^{45}$.

In sex offence cases, due to their nature, the power balance between parties is infringed. The case where the victim would be considered as an active party who would be asked for an opinion, to interface with the perpetrator, would reverse the imbalance of power that was created in the perpetration of the criminal offence.

Mercer et al. ${ }^{46}$ justifiably point out other possible benefits of the application of restorative justice to sex offences cases. According to them, offering a victim restorative justice in order to resolve a broken relationship with the perpetrator and to overcome the critical event, would help the victim to re-imagine a safer and positive future. That argument is of high importance since the establishment of communication between them would help the victim to overcome the fear and the shame, so the victim would be able to have a normal life again. How much that communication is important for victims is confirmed in a case in Denmark where the victim of a sex offence was interviewed by a therapist and said, "...the thing that would help the best would be talk with the offender" ${ }^{37}$. Additionally, according to Wosner ${ }^{48}$, scientific research made in Texas and Ohio shows that in $82 \%$ of cases where the dialog between perpetrators and sexual offence victims had been established, the victims felt rehabilitated, healed and in the process of personal growth.

Van Ness and Strong advocate application of restorative justice to sex offence cases, and they quote judge John Kelly, who said that „a purpose of the criminal law should be to heal the wounds caused by crime - wounds

45 Id.

46 Vince Mercer, Karin Sten Madsen, Marie Keenan and Estelle Zinsstag, Doing Restorative Justice In Cases Of Sexual Violence: A Practice Guide, 2015, 12.

47 Ibid., 11.

48 GundaWosner, "Developing Sexual Offenders Laws and Treatment in Europe", (2014): 102 . 
such as those of the rape victim from whom even the offenders' conviction and sentencing had not been enough ${ }^{\text {“49 }}$.

\subsection{Few examples of usage of restorative justice in sex offence cases}

The arguments mentioned above result from of a critical review of the implementation of forms of restorative justice in sex offence cases in the countries with deep history of its implementation, such as Australia, New Zealand, Canada and the USA. Mercer et al. give an example of the application of restorative justice to a case of a sexual offence that had been perpetrated in a family ${ }^{50}$. Girl Courtney was only 15 years old when her brother Lee (17) raped her. She told her mother about what had happened and her mother reported the offence to the police. Lee was sentenced to community supervision with a therapeutic program. The case direction-changing moment happened when their mother asked for restorative justice to be implemented in this case, since she wanted to discuss the critical event with family members to help her son reintegrate into his family ${ }^{51}$. The same author gives another example of successfully used restorative justice in the case Jo vs. Darren ${ }^{52}$, since the final outcomes of its application for the victim were: "emotional recognition and empathy, shame management, self-forgiveness and understanding why she was the target's3.

Another example of successful application of restorative justice is the "Restore Program" that has been applied in Arizona. It addresses date and acquaintance rape cases that had been perpetrated by offenders who violated the law for the first time $e^{54}$. In that way, the opportunity has been

49 They also mentioned the example of a rape case judged by judge John Kelly. Within the procedure the victim was told that she had no fault for the rape that had been committed to her. That was a moment when her psychological healing started. See more in: D. Van Ness and H. Strong, op. cit: 3.

50 Mercer et. al, Doing Restorative Justice In Cases Of Sexual Violence: A Practice Guide , 40 .

51 In that sense: Id., 40.

52 Id., 53.

53 Id., 53.

54 Anne-Marie McAlinden, Restorative Justice as a Response to Sexual Offending Addressing the Failings of Current Punitive Approaches (2008): 3. 
given for first-time offenders to divert themselves from the classical criminal procedure and they go through a restorative justice program that might be powerful enough to prevent them from recidivism. A similar approach is present in South Australia, where younger offenders, who plead guilty, can be diverted from the criminal procedure and can participate in certain forms of restorative justice ${ }^{55}$.

Furthermore, Restore Programs are two programs - one that has been applied in New Zealand and another one in the USA. They are applied to sexual offences and, according to Bolitho and Freeman ${ }^{56}$, they have received positive comments such as, "satisfying and procedurally fair" ${ }^{57}$. In New Zealand there are certain conditions given for usage of restorative justice in those cases. The conditions represent the true spirit of restorative justice since they consist of an imperative for bilateral voluntarism for commitment to restorative justice, from both the perpetrator and the victim. Moreover, their joint desire for restorative justice to be applied in their case should be visible through their formal agreement. Finally, when applied, restorative justice offers therapy and support for the victim..$^{58}$

\subsection{Which forms of restorative justice would be recommendable for sex offence cases?}

Among many authors ${ }^{59}$ there is agreement that if applied, the most recommendable forms of restorative justice would be mediation and restorative justice conferences. The substantive difference between mediation and conferences ${ }^{60}$ is in that the facilitator of mediation is a mediator (objective party) and in conferences there is wider society who might partici-

55 Id., 2.

56 Jane Bolitho and Karen Freeman, Abuse "The Use and Effectiveness of Restorative Justice in criminal justice systems following child sexual abuse or comparable harms", $R e$ port For The Royal Commission Into Institutional Responses To Child Sexual, 2016, 31.

57 Id.

58 Id.at 23.

59 Vince Mercer, Karin Sten Madsen, Marie Keenan and Estelle Zinsstag, 39; K. Daly and Proietti, 270; G. Wosner, 96, etc.

60 GundaWosner, "Developing Sexual Offenders Laws and Treatment in Europe", 2014, 96. 
pate in case resolution (family, social workers, etc. ${ }^{61}$. However, the aim of both approaches is to establish the ruined communication between parties through talk in a non-legal language. The applicability of conferences is, in our opinion, still disputable. If the active role of the family is dominant in those cases, what would happen in cases where the family doesn't support the victim, but as it sometimes happens, finds the victim is the one to be blamed for causing the victimization? That approach is, unfortunately, quite often visible in traditional societies. Together with those two forms of restorative justice, Mercer et al. emphasize the importance of the Face to Face Method ${ }^{62}$, which includes a small number of participants (which increases confidentiality of case) and that has at least two facilitators. The focus of this method is on both the victim and the offender, with the main aim of establishing a dialogue between them.

Even though there are respectful arguments that show the potential restorative justice risks in cases of sexual offences, the opposing arguments show that there are considerable benefits of the application of restorative justice and the potential possibilities for overcoming those risks. Having in mind, on the one hand that restorative justice aims to fix broken relationships and help both parties to overcome the critical event and on the other hand as previously mentioned, critical points within sexual offences should coexist with the retributive system. It should be an elective type of justice, instead of being an obligatory one. The decision on if it should be applied or not should be made after establishing some basic checkpoints ${ }^{63}$. First of all, it should be checked if the case is suitable for restorative justice, in

61 Daly and Proietti point out that restorative justice conferences emerged in New Zealand as response to Maori activists. See more in: GitanaProietti-Scifoni and Kathleen Daly, "Gendered violence and restorative justice: the views of New Zealand Opinion Leaders”, Contemporary Justice Review (2014), 270.

62 Vince Mercer, Karin Sten Madsen, Marie Keenan and Estelle Zinsstag, Doing Restorative Justice In Cases Of Sexual Violence: A Practice Guide, 39.

63 Those checkpoints are described in details in: Vince Mercer, Karin Sten Madsen, Marie Keenan and Estelle Zinsstag, Doing restorative justice in cases of sexual violence: a practice guide, Leuven Institute for Criminology(2015): 20-21. 
a sense to check whether there are statutory possibilities for its application (severity of the criminal offence in general). In that way, severe criminal offences would be automatically excluded from its application, preventing the possibility of their trivialization through easier approach towards the perpetrator. Then, having in mind one of the most important principle of criminal law is poenalia sunt restriguenda ${ }^{64}$, after checking case suitability, the case should be screened to determine whether that particular case of criminal offence is statutorily a fit for restorative justice and it would be recommendable to apply restorative justice. Case screening would mean that therapists ${ }^{65}$ should talk with the victim, in order to establish whether the victim's physical and psychological condition makes restorative justice capable in that instance. Only after those steps should restorative justice be applied. With its electiveness, it remains as an option for the victim to use it if he/she feels like it would help more than the classical retributive justice, while not mandating the victim to go through it and potentially to be secondarily victimized.

\section{A FEW NOTES OF APPLICABILITY OF RESTORATIVE JUSTICE TO SEXUAL OFFENCES IN BOSNIA AND HERZEGOVINA}

Having in mind the nature of restorative justice and the argument that in order to apply restorative justice to sexual offence cases, case suitability and case screening should be checked, in order to avoid possible negative effects on victim and to achieve all the benefits out of it, the few next pages will be devoted to testing the applicability of restorative justice in sex offences in Bosnia and Herzegovina. To this end, after a short overview on the situation of the application of restorative justice in general in Bosnia and Herzegovina, the analysis on testing case suitability will be done

64 It refers to the need to determine all relevant issues in criminal law through each case separately.

${ }_{65}$ Vince Mercer, Karin Sten Madsen, Marie Keenan and Estelle Zinsstag also recommend therapy to precede the decision upon restorative justice since in sex offences lots of emotions are involved and the will of victim could be questioned the best through the therapy. See 26. 
through a legal analysis of the relevant provisions of positive criminal law in Bosnia and Herzegovina.

\subsection{The Role of Restorative Justice in BH Criminal Justice System}

The imagination of concept of a justice system that would provide victims with important roles in the criminal case and where the victim-and-offender relation might be re-established, was turned into reality in 1998 in Bosnia and Herzegovina with the first Criminal Code brought after the war. ${ }^{66}$. The next criminal law reform in Bosnia and Herzegovina also allowed for restorative justice as a possibility. If asked, most scholars and practitioners would say that the establishment of restorative justice was a major step towards the harmonization of the criminal law of Bosnia and Herzegovina with international standards. Even though restorative justice is celebrating its 20th anniversary in Bosnia and Herzegovina, still most would say that the addition of restorative justice was merely an aim of its prescription, because when compared with its true application in practice, it remained more de iure, than de facto issue.

Nevertheless, according to the positive criminal law(s) of Bosnia and Herzegovina, restorative justice is introduced in the criminal system in a very fragmented level, through some institutes which, before concluding that there are forms of restorative justice, they need to deeply analyze the case in order to deduct whether restorative justice is appropriate. While some forms are applicable for adults, others are applied for juveniles only.

\section{a) Forms of restorative justice for adults}

There are three forms of restorative justice applicable to adults in the criminal legislation of Bosnia and Herzegovina ${ }^{67}$. They are: victim's proper-

66 Criminal Code Of Federation Of Bosnia And Herzegovina from 1998.

67 See more in: Ena Kazić, Rialda Ćorović (2019) "Restorative Justice Within Legal System of Bosnia and Herzegovina" in Restorative Approach and Social Innovation : From Theoretical Grounds to Restorative Practices, University of Padua, Italy, 170. 
ty claim $^{68}$, work for the general good ${ }^{69}$, and commitment of an offender to fulfilling certain obligations when pronouncing a conditional condem ${ }^{70}$.

One of the manifestations of restorative justice is present in the possibility of mediation, when a victim files a property claim. A property claim ${ }^{71}$ is the right of each victim whose personal or property rights have been endangered or damaged by a criminal offense $\mathrm{e}^{72}$ and it will be discussed in criminal proceedings (at the request of an authorized person) if it does not significantly delay that procedure. A property claim as such would not be an example of restorative justice if there were not a possibility for the court to propose the mediation procedure to the injured party ${ }^{73}$ and the defendant, if it finds that the property claim is of such nature that it would be desirable to finalize it through mediation. The proposal for the mediation may also be given by the injured party and the defendant until the completion of the main hearing.

The criminal substantive legislation of Bosnia and Herzegovina governs work for the common good at liberty ${ }^{74}$ (hereinafter "WCGL"), a sanction that was incorporated into all criminal laws in Bosnia and Herzegovina in 2003, that has its restorative elements. This sanction is used when a conditional/suspended sanction would not achieve the main aim of sanctions, but at the same time, execution of imprisonment would not be needed in order to achieve it. So, WCGL is basically the middle, the most convenient path. The conditions for imposing it are given in codes and they refer to the situation in which the court reviews and imposes a sentence of imprisonment for a term of up to one year, but in the same time determines that the imposed sentence (with the consent of the accused) will be replaced

68 Article 116 of CC FBH, Article 116 of CC BDBH, Article 85 of CC RS.

69 Article 44 of CC FBH, Article 44 of CC BDBH, Article 70 of CC RS.

70 Article 59 of CC FBH, Article 59 of CC BDBH, Article 47 of CC RS.

71 The property claim can refer to compensation of damages, a return of goods or annulment of a particular legal transaction. See: Article 116 of CC FBH, Article 116 of CC BDBH, Article 85 of CC RS.

72 Id.

73 Instead of using term „victim“, term „injured party“ has been used in the positive criminal law of Bosnia and Herzegovina.

74 See: Article 44 of CC FBH, Article 44 of CC BDBH, Article 70 of CC RS. In further text: WCGL. 
with work for the common good at liberty ${ }^{75}$. The restorative element in it is recognizable in the substance and type of the work itself, since it may be targeted for benefit of victim.

One of the warning measures that is a part of the criminal substantive law of Bosnia and Herzegovina ${ }^{76}$ is a conditional sentence and it contains elements of restorative justice in the broader sense. The court determines to sanction the offender and at the same time determines that it will not be executed, if the convicted person, during a certain period of time ${ }^{77}$ does not commit a new criminal offense. A suspended sentence is used for minor offences, when maximum imprisonment does not exceed two years or a money fine ${ }^{78}$. The restorative element may be found in a situation when together with a conditional sentence, the court may impose the convicted person to compensate the damage caused by his/her criminal offense.

\section{b) Forms of restorative justice for juveniles}

When it comes to juveniles ${ }^{79}$, there are three forms of restorative justice that might be applied to juveniles: educational recommendations ${ }^{80}$, police warning, and delayed pronouncement of the sentence of juvenile imprisonment.

75 See: Article 44 of CC FBH, Article 44 of CC BDBH, Article 70 of CC RS.

76 See: Articles 58-65. CCBH, articles 62-68. CCFBH, articles 46-52 CCRS, articles 59-68. CCBD.

77 That period can't be shorter than one or longer than five years. It is so-called: time of probation.

78 When deciding whether to pronounce a suspended sentence, the court shall, having in mind the purpose of the conditional conviction, take into account, in particular, the personality of the offender, his earlier life, his conduct after the committed criminal offence, the degree of guilt and other circumstances under which the criminal offence was committed. Articles 58-65. CCBH, Articles 62-68. CCFBH, Articles 46-52 CCRS, Articles 59-68. CCBD.

79 See more in: Ena Kazić, Rialda Ćorović (2019) "Restorative Justice Within Legal System of Bosnia and Herzegovina" in Restorative Approach and Social Innovation : From Theoretical Grounds to Restorative Practices, University of Padua, Italy, 174.

80 See: Articles 24-28 of CC FBH, Articles 24-28 of CC BDBH, Articles 24-28 of CC RS. 
Educational recommendations are alternative measures in the criminal law of Bosnia and Herzegovina. They may be used when the objective and the subjective conditions of the particular case have been fulfilled: while the objective condition is that for the offence prescribed, the sanction is a monetary fine or imprisonment not to exceed three years, while among subjective conditions there are inter alia: that the juvenile shows an interest to reconcile with the victim ${ }^{81}$ and that the victim gives consent for reconciliation ${ }^{82}$. While the first element of restorative justice may be recognized through the will of the perpetrator for reconciliation with the victim, which shows the possibility of fixing the broken relationship and their conflict, the remaining restorative justice element is recognizable through the type of the possible educational recommendations that could be imposed on a juvenile. There are six of them ${ }^{83}$ and out all of them only two have restorative justice nature: a personal apology to the injured party and monetary compensation.

Regarding the police warning, according to Article 23 of the code on the protection and dealing with juveniles in criminal proceedings in Bosnia and Herzegovina, "it may be given if, objectively, a monetary fine or imprisonment not to exceed 3 years is prescribed by the law, for the criminal offence, and subjectively: if the perpetrator has willingly plead guilty, there is enough evidence that the crime was committed, and a police warning hadn't been imposed to that person before". The restorative justice element may be found in it if it is observed from a wider perspective - with a police warning, the aim of punishing would be achieved without punishing or having a criminal procedure at all. That brings efficiency to the criminal proceedings and therefore benefiting society as a whole.

81 Article 24 (1) of CC FBH, Article 24 (1) of CC BDBH, Article 24 (1) CCRS.

82 See other conditions: Article 24 (2) of CC FBH, Article 24 (2) of CC BDBH, Article 24 (2) CCRS.

83 Those are: Personal apology to the injured party; Compensation of damage to the injured party; Regular school attendance or Working for a humanitarian organisation or local community; Accepting an appropriate job; Treatment in an adequate health institution and Attending instructive, educational, psychological and other forms of counselling. 


\subsection{Brief Overview on the Suitability of Restorative Justice for Sexual Offences in BH Positive Law}

Having in mind the forms of restorative justice that have been prescribed by $\mathrm{BH}$ positive law, in this part of paper, we will bring incriminated sexual offences to that background in order to establish suitability of restorative justice for them.

The Criminal Law in Bosnia and Herzegovina, due to its specific constitutional organization, has been distributed on two levels: the state level and the level of entities (Federation of Bosnia and Herzegovina, Republika Srpska, and Brčko District BH), through the Criminal Code of Bosnia and Herzegovina ${ }^{84}$, the Criminal Code of Federation of Bosnia and Herzegovina $^{85}$, the Criminal Code of Republika Srpska ${ }^{86}$, and the Criminal Code of Brčko District $\mathrm{BH}^{87}$.

There is no special chapter within the CCBH governing sex offences because that group of criminal offences has been prescribed by entity-level codes. In XIX Chapter of the CCFBH titled "Crimes against sexual liberties and morality" those sexual offences have been prescribed: rape, sexual intercourse with a helpless person, sexual intercourse with abuse of a position, sexual intercourse, sexual intercourse with a child, indecent activities, sexual satisfaction in front of a child or juvenile, inducement to prostitution, exploitation of a child or juvenile for pornography, child pornography, incest, human trafficking and organized human trafficking ${ }^{88}$.

The same offences have been prescribed by the CCBD in its XIX chapter $^{89}$. The CCRS differentiates sexual offences perpetrated towards adult and towards juveniles, so Chapter $\mathrm{XIV}^{90}$ and Chapter $\mathrm{XV}^{91}$ refer to the offences against sexual integrity: rape, sexual blackmail, sexual intercourse with a helpless person, sexual intercourse with the abuse of a position,

\footnotetext{
84 Further in text: CCBH.

85 Further in text: CCFBH.

86 Further in text: CCRS.

87 Further in text: CCBD.

88 Articles 203-214 of CC FBH.

89 Articles 200-211 of CC BDBH.

90 Articles 165-172 of CCRS.

91 Articles 172-181 of CCRS.
} 
inducement to prostitution, sexual harassment, sexual intercourse with a child younger than the age of fifteen, sexual abuse of a child younger than the age of fifteen, instructing a child to attend child pornography, exploiting children for pornography, exploiting children for pornographic performances, introducing children to pornography, exploiting a computer network or communicating with other technical means for executing criminal acts of sexual abuse or exploitation of the child, satisfaction of sexual urges in front of others, and inducement of the child to prostitution.

As it has been mentioned above that in global mediation vis a vis property claim, work for the common good at liberty, a conditional sentence, police warning and educational recommendations are possible forms/ manifestations of restorative justice in the $\mathrm{BH}$ legal system, after testing the objective condition (sanction prescribed for sex offences) for application of those forms of restorative justice (suitability check), we have come to the following conclusions:

Mediation and property claim, according to the positive criminal codes, may be applied to all basic forms of sexual offences since its objective criteria is referring to all criminal offences. Yet, when it comes to mediation, having in mind the specific state of the victims of sexual violence, in the authors' opinion, on top of the main rules for becoming a mediator ${ }^{92}$, additional conditions should be imposed. Mediators should be specialized and experienced for work with the victims of sexual violence. Their active involvement is crucial for avoiding the negative aspects that might happen in bringing a perpetrator and a victim to the same place. Their knowledge and experience may prevent possible stress and conflict between the parties in mediation.

Additionally, when it comes to property claim, even though it is an open possibility for application in the positive law, statistical data shows that in practice it is seldom used for cases of the war crimes (when rape

92 They have been prescribed in the Book of Rules for Mediators. Conditions for becoming a mediator include: faculty degree, registered practice and training, mediators in cases of sexual violence. 
is one of the actions). For example, in their paper, Šimić and Kazićc ${ }^{33}$, are referring to the decisions on property claims within war crime cases. In the practice of the State Court of Bosnia and Herzegovina in the cases of war crimes, "out of 162 final verdicts, the decision on the property claim within the criminal procedure was made in 5 cases and out of the 182 first degree verdicts that have not yet been finalized, this decision was made in 2 cases" ${ }^{\prime \prime}$.

Generally, based on efficiency, most of the property claims are transferred to be decided in civil proceedings. Solving those claims in civil proceedings instead of criminal ones would not be a problem, if there were not cases where witnesses (who are victims) are protected by pseudonym or other forms of protection and since in civil procedure a claimant's identity should be known, there is a risk of either not bringing claims in civil proceedings because of fear of uncovering the true identity of a victim or of making a claim that will reveal the identity of a victim.

Since a conditional sentence may be applied in cases when in concreto the sanction would be a monetary fine or imprisonment not to exceed two years, this form of restorative justice may be applied in the Federation of Bosnia and Herzegovina and Brčko District $\mathrm{BH}$ for only basic forms of: rape $^{95}$, sexual intercourse with a helpless person ${ }^{96}$, sexual intercourse with abuse of a position ${ }^{97}$, coercion to sexual intercourse ${ }^{98}$, sexual intercourse

93 Goran Šimić and Ena Kazić, The Contribution of Prosecutors to the Failure of Damage Claims of Victims in War Crimes Trials at the Court of Bosnia and Herzegovina,7(12) ILIRIA INT'L REV (2017): 12.

94 Most of them are related to sex violence actions within war crimes. Id., 12.

95 Special minimum prescribed is 1 year of imprisonment and special maximum is 10 years (Example from Article 203. (1) CC FBH, Article 200. (1) CC BDBH).

96 Special minimum prescribed is 1 year of imprisonment and special maximum is 8 years (Example from Article 204. (1) CC FBH, 201. (1) CC BDBH).

97 Special minimum prescribed is 3 months of imprisonment and special maximum is 3 years (Example from Article 205. (1) CC FBH, 202. (1) CC BDBH).

98 Special minimum prescribed is 6 months of imprisonment and special maximum is 5 years (Example from Article 206. (1) CC FBH, 203. (1) CC BDBH). 
with a child ${ }^{99}$, indecent activities ${ }^{100}$, sexual satisfaction in front of a child or juvenile ${ }^{101}$, inducement to prostitution ${ }^{102}$, exploitation of a child or juvenile for pornography ${ }^{103}$, child pornography ${ }^{104}$ and incest ${ }^{105}$. It cannot be applied in the cases of human trafficking ${ }^{106}$ and organized human trafficking ${ }^{107}$ because the minimum prescribed by law is much higher than the term prescribed as objective condition (even when there is mitigation of sanctions).

Since the penal policy is stricter in the Republika Srpska and provisions are different from those in $\mathrm{FBH}$ and $\mathrm{BDBH}$, through the same analysis of case suitability, this form of restorative justice is applicable for: sexual blackmail ${ }^{108}$, inducement for prostitution ${ }^{109}$, sexual harassment ${ }^{110}$,

99 Special minimum prescribed is 1 year of imprisonment and special maximum is 8 years (Example from Article 207. (1) CC FBH, 204. (1) CC BHBH).

100 Special minimum prescribed is 3 months of imprisonment and special maximum is 3 years (Example from Article 208. CC FBH, 205. CC BDBH).

101 Special minimum prescribed is 3 months of imprisonment and special maximum is 3 years (Example from Article 209. CC FBH, 206. CC BDBH).

102 Special minimum prescribed is 1 year of imprisonment and special maximum is 5 years (Example from Article 210. (1) CC FBH). In Brčko District minimum is lower as it is 6 months of imprisonment (Article 207. CC BDBH).

${ }^{103}$ Special minimum prescribed is 1 year of imprisonment and special maximum is 5 years (Example from Article 211. (1) CC FBH, Article 208. CC BDBH).

${ }_{104}$ Prescribed money fine or imprisonment of maximum 1 year (Example from Article 212. CC FBH, Article 209. CC BDBH).

${ }^{105}$ Prescribed money fine or imprisonment from 6 months to 2 years (Example from Article 213. CC FBH). In BD BH, according to Article 210. CC BDBH, prescribed sanctions are money fine or imprisonment of maximum 1 year.

106 Prescribed minimum of sanction is at least 5 years of imprisonment (Example from Article 210.a (1) CC FBH, Article 207a (1) of CC BDBH).

107 Prescribed minimum of sanction is at least 10 years of long term imprisonment (Example from Article 210.b (1) CC FBH, 207.b (1) CC BDBH).

${ }^{108}$ Criminal sanction prescribed by Article 166. (1) is imprisonment of one to eight years.

${ }^{109}$ Criminal sanction prescribed by Article 168. Of CCRS is imprisonment from 6 months to 5 years and money fine.

${ }^{110}$ Criminal sanction is imprisonment up to 2 years, according to Article 170. (1) CCRS. 
indecent activities ${ }^{111}$, forcing a child to attend sexual intercourse ${ }^{112}$, exploitation of children for pornography ${ }^{113}$, offences of using and introducing children with pornography ${ }^{114}$, exploiting a computer network or communicating with other technical means for executing criminal acts of sexual abuse or exploitation of the child ${ }^{115}$, satisfaction of sexual urges in front of others ${ }^{116}$, and inducement of the child to prostitution ${ }^{117}$. The remaining criminal offences have much harsher penalties, with a mandatory minimum that exceeds the objective condition and therefore are not suitable for restorative justice.

If we have in mind the objective condition for the application of the work for the common good at liberty ${ }^{118}$ which refers to the situation when the court determines a sanction of 1 year of imprisonment, when compared with sanctions for sexual offences in concreto (and prescribed minimum of sanction), this form of restorative justice-natured sanction may be applied to sex offence cases, which is the case with a conditional sentence.

Finally, regarding educational recommendations and police warning within provisions for sexual offences, if checked from the point of prescribed sanctions for those criminal offences, they may be applied in the cases of ${ }^{119}$ : a sexual intercourse with the abuse of a position, indecent activities, sexual satisfaction in front of a child or juvenile, child pornography and incest. Therefore, they are not applicable to other sex offences because they are more severe offences for which restorative justice would not be suitable.

${ }^{111}$ Is punishable by imprisonment of up to 2 years (Article 171. CCRS).

112 Article 174. (1) CCRS prescribes sanction of imprisonment from 6 months to 5 years.

113 Sanction is 6 months to 5 years, according to Article 175. CCRS.

${ }^{114}$ Articles 176. (imprisonment of 6 months to 5 years) and 177. (imprisonment of 6 months to 3 years) of CCRS.

115 Article 178. (1) of CCRS prescribes sanction of 1 to 5 years of imprisonment.

116 Article 179. of CCRS prescribes imprisonment of 2 to 8 years.

117 Both money fine and imprisonment of 1-8 years of imprisonment are prescribed by CCRS.

118 As prescribed in CC FBH and CC BDBH.

119 See footnotes 90-113. 


\section{CONCLUSION}

Restorative justice is, without any doubt, the approach that views socially unacceptable behavior and responds to it in a fundamentally different way, unlike the retributive criminal justice system. It has gained increasing credibility as a powerful alternative to the traditional responses to crime. In this paper it is discussed whether it is recommendable to apply some forms of restorative justice to sex offence cases. Namely, those cases of intimate relation between the perpetrator and the victim, the level of victimization and stress, and its deep consequences do some scholars find unsuitable for restorative justice to be applied to.

We have shown what positive aspects that restorative justice leaves on victims. The satisfaction that victim might feel for the possible remorse of a perpetrator and the fact that they are crucial parties of the process might have a positive effect on the victim. That is also the way how the victim can regain balance lost in the relationship with the perpetrator and finally can find closure which is crucial for the victim to continue with her/his life. Additionally, the shame and remorse that the perpetrator might feel after the interface with the victim can prevent him/her of committing a new criminal offence.

The arguments against restorative justice that consist of fear of secondary victimization might be overcome easily, when each case is screened by a specialist and therapists who would establish whether restorative justice should be applied or not in that particular case. Together with that measure, restorative justice should be checked for its suitability that is usually defined by the criminal law which offers objective conditions for its application.

Through this paper it is shown that restorative justice in Bosnia and Herzegovina is accepted in fragments, mostly due to the lack of understanding of its importance. Forms/manifestations of restorative justice in $\mathrm{BH}$ legal system are mediation within property claim, work for the common good at liberty, conditional sentence (adults), educational recommendations and police warning (juveniles). Most of them are applicable to basic forms of sexual offences, except for the conditional sentence and work for common good on liberty, which cannot be applied in the cases of human trafficking and organized human trafficking. In the cases of media- 
tion, it has been noted that one should be extremely careful in considering its application; the effect of interface of the victim and the perpetrator on the victim should go through checkpoints and mediators should be specialized for work with the victims of sexual offences in order to prevent possible secondary victimization. Regarding property claim, even though it is governed as a possibility and as a right of the wronged party, it is often left for the civil court to decide upon them. This is problematic in the cases where victims, as witnesses, are protected by measures that mask their identity since in civil proceedings a claimant's identity should be known.

In the authors' opinion, limitation in the application of restorative justice to sexual offences should be considered only for severe cases with aggravating elements (such as aggravated consequences of the offence death or injury, or perpetration of an offence several times towards the same person, or in a cruel way or that person is a child). Exactly this approach is accepted in Bosnia and Herzegovina as well, since most forms of restorative justice are applicable only to main (basic) forms of those offences. So, it is possible to conclude that the positive law of Bosnia and Herzegovina provides the opportunity for the application of those forms of restorative justice to the above-mentioned cases. The recommendation for reaching optimum use of restorative justice in general would be to let restorative justice be an elective form of justice (elected jointly by a perpetrator and a victim), so if they want this kind of resolution of their conflict, it should be offered to them. Alternatively, if neither party elects for restorative justice, then it should not be mandatory.

\section{REFERENCES}

1. Armour, Marilyn. "Restorative Justice: some facts and history". [last access:20.07.2018], https://charterforcompassion.org/restorative-justice/restorative-justice-some-facts-and-history.

2. "A Report on Reparations and Remedies for Victims of Sexual and Gender based Violence". "A Report for REDRESS" "2016. Oxford: University of Oxford, [last access: 02.06.2018], http://link.springer.com/article/10.1007\%2Fs11115-005-5093-8\#page-1. 
3. Bazemore, Gordon, O’Brien, Sandra, Carey, Mark. "The Synergy and Substance of Organizational and Community Change in the Response to Crime and Conflict: The Emergence and Potential of Restorative Justice (online)". 2005. Public Organisation Review, vol. 5. - No. 4./2005. Springer Science \& Business Media B.V., Dordrecht.

4. Bazemore, Gordon, Umbreit, Mark. 1998. Guide for Implementing the Balanced and Restorative Justice Model, Washington: U.S. Department of Justice.

5. Bergseth, K., Bouffard, J. 2007. The Long-Term Impact of Restorative Justice Programming for Juvenile Offenders, Journal of Criminal Justice, vol. 35., No 4., Amsterdam: Elsevier, pp. 433.-451.

6. Biff, Emanuella. 2016. Practice Guide to restorative justice Services: The Victims' Directive: Challenges and opportunities for Restorative Justice. Bruxell.

7. Bolitho, Jane and Freeman, Karen. 2016. "The Use and Effectiveness of Restorative Justice in criminal justice systems following child sexual abse or comparable harms". "Report for the Royal Comission into Institutional Responses to Child Sexual Abuse or comparable harms".

8. Cetinić, Marinka. 1995. "Pogled na pitanje da li je potrebno preispitivanje inkriminacije silovanja". "Anali Pravnog fakulteta u Beogradu”. Belgrade.

9. Christi, Nils. 1977. "Conflicts as property". "The British Journal on Criminology".

10. Clark, Janine Natalya. 2008. "The Three Rs: Retributive Justice, Restorative Justice and Reconciliation". "Contemporary Justice Review", vol. 11./No. 4./2008. Oxford: Routledge Taylor \& Francis Group. Available on: http:// www.tandfonline.com/toc/gcjr20/11/4.

11. Code on Criminal Proceedings of Federation of Bosnia and Herzegovina, Official Gazzette of FBH, No: 35/03, 37/03, 56/03, 78/04, 28/05, 55/06, 27/07, 53/07, 9/09, 12/10, 8/13 and 59/14.

12. Code on Criminal Proceedings of Bosnia and Herzegovina, Official Gazzette BH, No: 3/03, 32/03, 36/03, 26/04, 63/04, 13/05, 48/05, 46/06, 76/06, 29/07, 32/07, 53/07, 76/07, 15/08, 58/08, 12/09, 16/09, 93/09 and 72/13.

13. Code on Criminal Proceedings of Brčko District of Bosnia and Herzegovina, Official GazzetteBDBiH, No: 10/03, 48/04, 6/05, 14/07, 19/07, 21/07, 2/08, 17/09 and 9/13;

14. Code on Criminal Proceedings of Republika Srpska, Official GazzetteRS, No: 53/12).

15. Ćopić, Sanja. and Nikolic-Ristanovic,Vesna. 2012. "Developing alternative understandings of security and justice through restorative justice approaches 
in intercultural settings within democratic societies". Viktimolosko drustvo Srbije.

16. Ćopić, Sanja. 2010. Restorativna pravda i krivičnopravni sistem (doktorska disertacija). Niš: Pravni fakultet Univerziteta u Nišu.

17. Ćopić, Sanja. 2007. „Pojam i osnovni principi restorativne pravde”. „Temida”, vol. 10. - No. 1./2007, Beograd: Viktimološko društvo Srbije.

18. Cragg, Wesley. 1992. The Practice of Punishment: towards a Theory of Restorative Justice. New York.

19. Criminal Code of Bosnia and Herzegovina, Official Gazzette of $\mathrm{BiH}$, No.: 3/03, 32/03, 37/03, 54/04, 61/04, 30/05, 53/06, 55/06, 32/07, 8/10, 47/14, $22 / 15,40 / 15$.

20. Criminal Code of Brčko District BH, Official Gazette BD, No. 10/03, 45/04, 6/05, 21/10, 47/11, 52/11, 33/13.

21. Criminal Code of Federation of Bosnia and Herzegovina, Official Gazette of FBH, No. 36/06, 37,03 21/04, 69/04, 18/05, 42/10, 42/11, 59/14, 76/14, $46 / 16$.

22. Criminal Code of Federative Nation Republic of Yugoslavia, 1951.

23. Criminal Code of Republic Srspka, Official Gazzette of RS, No. 64/17.

24. Criminal Code of Republic of Germany, Federal Legal Gazzette No. 945/98.

25. Criminal Code of Republic of France, Official Gazzette No. 684/92, 25/93, 15/95, 06/99, 11/99, 37/99, 22/01, 03/03, 24/03, 79/03, 17/05, 43/05, 48/07, 09/09, 13/10, 42/10, 10/11, 15/14).

26. Daly, Kathleen. 2005. „Restorative vs. Retributive Justice“. Center for crime and justice studies, No. 60.

27. Gavrielides, Theo. 2007. Restorative Justice Theory and Practice: Addressing the Discrepancy, Helsinki: European Institute for Crime Prevention and Control.

28. Hudson, Barbara. 1998. "Restorative Justice: The Challenge of Sexual and Racial Violence". "Journal Of Law And Society", No.2: 237-256.

29. Johnstone, Gerry and Van Ness, Daniel W. (ed.). 2007. Handbook of Restorative Justice, Willan Publishing.

30. Kazić, Ena and Ćorović, Rialda (2019) "Restorative Justice Within Legal System of Bosnia and Herzegovina" in Restorative Approach and Social Innovation : From Theoretical Grounds to Restorative Practices, University of Padua, Italy.

31. Keenan, Marie. and Zinsstag, Estelle. 2014. „Restorative Justice and Sexual Offences". "Monatsschrift fur Kriminologie und Strafenrechtsreform".

32. McAlinden, Anne-Marie (2008) Restorative Justice as a Response to Sexual Offending - Addressing the Failings of Current Punitive Approaches. 
33. Mercer, Vince, Madsen, Karin Sten, Keenan, Marie and Zinsstag, Estelle. 2015. Doing Restorative Justice in Cases of Sexual Violence: A practice guide. Belgium: Leuven Institute of Criminology.

34. Mills, Linda G., Grauwiler, Peggy, Pezold, Nicole. 2006. "Enhancing Safety and Rehabilitation in Intimate Violence Treatments: New Perspectives". Public Health Reports 121, no. 4: 363-368. [last access: 29.05.2018], https:// www.ncbi.nlm.nih.gov/pmc/articles/PMC1525346/.

35. Mirosavljević, Anja. 2010. „Modeli restorativne pravde u svijetu za mlade u sukobu sa zakonom i pregled istraživanja njihove učinkovitosti“. „Kriminologija i socijalna integracija“. Zagreb: Edukacijsko-rehabilitacijski fakultet Sveučilišta u Zagrebu, vol. 18., br. 1., pp. 53.-64.

36. Mrvić-Petrović, Nataša and Đorđević, Đorđe. 1998. Moć i nemoć kazne. Beograd: Vojnoizdavački zavod: 89.- 90.

37. Petrović, Borislav and Meško, Gorazd. 2004. Kriminologija. Sarajevo: University in Sarajevo.

38. Proietti-Scifoni, Gitana and Daly, Kathleen. 2011. "Gendered violence and restorative justice: the views of New Zealand Opinion Leaders". "Contemporary Justice Review": 1-41.DOI: 10.1080/10282580.2011.589666.

39. Šimić, Goran, Kazić, Ena. 2017. „The contribution of prosecutors to the failure of damage claims of victims in war crimes trials at the Court of Bosnia and Herzegovina“. „Iliria International Review“, Vol. 7, No. 2: 85-92.

40. Van Ness, Daniel W. and Strong, Karen Heetderks. 2014. Restoring Justice: An introduction to restorative justice, Routledge.

41. Wheeldon, Johannes. 2009. "Finding Common Ground: Restorative Justice and its Theoretical Construction(s) (online)". "Contemporary Justice Review”. Oxford: Routledge Taylor \& Francis Group, vol. 12.- No 1./2009: 91-100.

42. World Health Organization Report on Sexual and Reproductive Health. [last access: 29.05.2018], https://www.who.int/reproductivehealth/topics/violence/sexual_violence/en/.

43. Wosner, Gunda. 2014. "Developing Sexual Offenders Laws and Treatment in Europe", "Monatsschrift fur Kriminologie und Strafrechtsreform", Vol 97, No. 1.

44. http://www.cscsb.org/restorative_justice/retribution_vs_restoration.html.

45. "The Origins of Restorative Justice". [last access: 29.05.2018], http://www. restorativeapproaches.eu/origins.

46. "Preventing sexual violence". [last access: 29.05.2018], https://www.cdc.gov/ violenceprevention/sexualviolence/definitions.html. 
